\title{
Expression Profile Screening and Bioinformatics Analysis of circRNA, LncRNA, and mRNA in Acute Myeloid Leukemia Drug- Resistant Cells
}

\author{
Akut Myeloid Lösemi llaç-Dirençli Hücrelerde circRNA, LncRNA, ve mRNA Ekspresyon \\ Profili Tarama ve Biyoinformatik Analizi
}

(D) Meiling Li1,2, (D) Fuxue Meng2, (D) Quanyi Lu¹

1Zhongshan Hospital Affiliated to Xiamen University, Department of Hematology, Xiamen, China

2The Third Affiliated Hospital of Guizhou Medical University, Department of Hematology and Rheumatology, Duyun, China

\section{Abstract}

Objective: Acute myeloid leukemia (AML) is a highly heterogeneous hematological malignancy, and drug resistance and relapse are key factors in the failure of leukemia treatment. Studies have increasingly shown that circRNA and LncRNA play important roles in the development of tumors, but their roles remain unclear in the mechanism of AML resistance.

Materials and Methods: Resistant AML cell line HL-60/ADM (adriamycin, ADM) was constructed and circRNA, LncRNA, and mRNA expression profiles were screened followed by high-throughput sequencing. Bioinformatics analysis was then carried out, and the circRNA-miRNA ceRNA network was constructed and confirmed using qRT-PCR analysis.

Results: A total of 1824 circRNAs, 2414 LncRNAs, and 5346 mRNAs were screened for differentially expressed genes. Enrichment analysis was performed utilizing Gene Ontology and the Kyoto Encyclopedia of Genes and Genomes, which mainly involved protein domain specific binding, transforming growth factor- $\beta$ (TGF- $\beta$ ) receptor, and cellular metabolism. The mTOR signaling pathway, MAPK signaling pathway, RAP1 signaling pathway, and Akt signaling pathway were closely related to drug resistance.

Conclusion: Our study provides a systematic outlook on the potential function of ncRNA in the molecular mechanisms of resistant AML cells. Hsa-circ-0000978 and hsa-circ-0000483 might serve as potential prognostic biomarkers and therapeutic targets of AML resistance.

Keywords: Acute myeloid leukemia, Drug resistance, CircRNA, LncRNA, Bioinformatics analysis

\section{Öz}

Amaç: Akut myeloid lösemi (AML) oldukça heterojen bir hematolojik malignitedir, ve tedavi başarısızlığında ilaç direnci ve nüks anahtar rol oynamaktadır. Çalışmalar, circRNA ve IncRNA'nın tümör gelişiminde önemli rol oynadığını artarak göstermektedir, ancak AML direnç mekanizmasında rolleri belirsizliğini korumaktadır.

Gereç ve Yöntemler: Dirençli AML hücre hattı HL-60/ADM (adriamisin, $A D M)$ oluşturuldu ve circRNA, LncRNA, ve mRNA ekspresyon profilleri yüksek-kapasitede dizileme sonrası tarandı. Sonra biyoinformatik analiz gerçekleştirildi ve circRNA-miRNA ceRNA ağı oluşturuldu ve qRT-PCR analizi kullanılarak doğrulandı.

Bulgular: Farklı ifade edilen genler için toplam 1824 circRNA, 2414 LncRNA, ve 5346 mRNA tarandı. Başlıca protein domain spesifik bağlama, transforme edici büyüme faktörü- $\beta$ (TGF- $\beta$ ) reseptörü, ve hücresel metabolizma ile ilgili 'Gene Ontology' ve 'Kyoto Encyclopedia of Genes and Genome' kullanılarak zenginleştirme analizi gerçekleştirildi. mTOR sinyal yolağı, MAPK sinyal yolağı, RAP1 sinyal yolağı ve Akt sinyal yolağı ilaç direnci ile yakından ilişkili idi.

Sonuç: Çalışmamız, dirençli AML hücrelerinin moleküler mekanizmasında ncRNA'ın potansiyel fonksiyonuna sistematik bir bakış açısı sağlamıştır. Hsa-circ-0000978 ve hsa-circ-0000483 potansiyel prognostik biyogöstergeler ve AML direncinin terapötik hedefleri olarak işlev görebilirler.

Anahtar Sözcükler: Akut myeloid lösemi, İlaç direnci, CircRNA, LncRNA, Biyoinformatik analiz 


\section{Introduction}

Acute myeloid leukemia (AML) is a highly heterogeneous hematological malignancy. Although its treatment has made significant progress, the prognosis is still unsatisfactory. Recurrence and drug resistance are the main factors [1]. At present, there are many studies on the molecular mechanisms of AML resistance $[2,3]$. However, with the development of bioinformatics, the epigenetic mechanism in the pathogenesis of AML still remains unclear.

Among human transcripts, about $10 \%-20 \%$ are proteinencoding RNA, and the remaining 80\%-90\% are noncoding RNAs (ncRNAs) [4,5]. Long noncoding RNAs (LncRNAs) are a class of noncoding RNAs that regulate gene expression at the transcriptional or posttranscriptional level [6]. LncRNA plays an important regulatory role in the drug resistance process. $\mathrm{Li}$ et al. [7] reported that the LncRNA HOTIP can promote the development of pancreatic cancer and regulate gemcitabine resistance by regulating HOXA13, while HOTTIP regulates cisplatin resistance in osteosarcoma cells by activating the Wnt/ $\beta$-catenin pathway [8]. In addition, Qu et al. [9] found that in sunitinib-resistant renal cell carcinoma, when FOXO and AKT expression decreased, LncRNA increased, knocking out LncRNA and then reversing drug resistance. Endogenous competition between mir-34 and mir-449 promotes the expression of AXL and c-MET in sunitinib-resistant renal cell carcinoma to regulate the drug resistance process, confirming that LncRNA can be used as a target to repair drug resistance. Circular RNAs (circRNAs) are novel noncoding RNAs characterized by a covalently closed structure with nonrandom spiking and RNase degradation resistance $[10,11]$. CircRNA is present in the cytoplasm and is extremely abundant and highly conserved and stable in the blood [12]. CircRNAs are increasingly found in various diseases and show cell or tissue specificity $[13,14,15]$.

At present, the molecular mechanism of LncRNA and circRNA in resistant $A M L$ cells remains unclear. In this study, highthroughput sequencing of HL-60 and HL-60/ADM (adriamycin, ADM) was performed utilizing Gene Ontology (GO) and the Kyoto Encyclopedia of Genes and Genomes (KEGG). A circRNAmiRNA ceRNA network was constructed to provide new therapeutic targets and the theoretical basis for treatment of drug resistance in AML.

\section{Materials and Methods}

\section{Materials}

HL-60 cells were donated by Professor Lu Quanyi of the Key Laboratory of Hematology, Xiamen University, Xiamen, China. Basic RPMI 1640 Medium (GIBCO, Carlsbad, CA, USA), fetal bovine serum (FBS; ScienCell, Carlsbad, CA, USA), adriamycin (Haizhenghuirui Pharmaceutical Co. Ltd., Fuyang, Zhejiang,
China), the Cell Counting Kit-8 (Dojindo, Tokyo, Japan), RIPA buffer (Beijing Solarbio Science \& Technology Co. Ltd., Beijing, China), the BCA Protein Assay Kit and One-Step Western Kit HRP (Beijing Kangwei Century Biotechnology Co. Ltd., Beijing, China), GAPDH monoclonal antibody (ImmunoWay Biotechnology Co, Plano, TX, USA); P-gp monoclonal antibody (Abcam, Cambridge, MA, USA), and Immobilon Western Chemiluminescent HRP Substrate (Millipore Corp., Billerica, MA, USA) were also obtained.

\section{Methods}

\section{Cell Culture and Drug Resistance Induction}

HL-60 cells were incubated in basic RPMI 1640 Medium containing 10\% FBS, $100 \mu \mathrm{g} / \mathrm{mL}$ streptomycin, and $100 \mathrm{U} / \mathrm{mL}$ penicillin at $37{ }^{\circ} \mathrm{C}$ and $5 \% \mathrm{CO}_{2}$ under saturated humidity conditions after recovery. The liquid was changed once every 2 days, and $10^{6}$ cells/mL were amplified at a 1:3 ratio. ADM induction was performed in HL-60 cells by combining the concentration gradient increasing method and the impact method (high-dose intermittent induction) as referenced in the literature [16]. The initial induction concentration was $0.1 \mu \mathrm{g} / \mathrm{mL}$, shock induction was performed for $1 \mathrm{~h}$, and culturing was continued until HL-60 cells grew and proliferated normally at $1 \mu \mathrm{g} / \mathrm{mL}$ ADM. It took 8 months to successfully induce ADM resistance in $\mathrm{HL}-60$ cells.

\section{CCK-8 Assay and Cell IC ${ }_{50}$ Values}

HL-60 cells were collected and centrifuged at $1000 \mathrm{rpm} / \mathrm{min}$ for 5 min, and then they were resuspended in RPMI 1640 Medium and counted. Furthermore, $10^{4}$ cells of cell suspensions of 100 $\mu \mathrm{L}$ were placed in 96 -well plates at $37^{\circ} \mathrm{C}$ in a $5 \% \mathrm{CO}_{2}$ incubator for culturing for $24 \mathrm{~h}$. ADM was added with differences in concentrations of $10 \mu \mathrm{L}$ and cells were incubated for $24 \mathrm{~h}$, and then $10 \mu \mathrm{L}$ of CCK-8 solution was added to each well. Culture plates were further incubated in the incubator for $4 \mathrm{~h}$. OD values were measured and data were collected to calculate $I_{50}$ values, or ADM concentrations required for $50 \%$ inhibition in vitro.

\section{Western Blot Detection of the Expression of Drug-Resistant Protein}

RIPA buffer was added with phenylmethanesulfonyl fluoride to collect the cells showing logarithmic growth, and proteins were extracted from the cells. Protein concentration was determined using the BCA Protein Assay Kit. Protein samples containing sample buffer were denatured for $5 \mathrm{~min}$ in boiling water. SDS-PAGE electrophoresis was performed with $25 \mu \mathrm{g}$ of sample in each hole with the addition of $5 \mu \mathrm{L}$ of prestained protein marker. When the bromophenol blue dye ran off the gel layer, the electrophoresis was terminated, and further experiments were performed on a $35 \mathrm{~mA}$ transmembrane overnight. The One-Step Western Kit HRP was used according to the manufacturer's instructions. Rabbit P-gp antibody, antibody pretreatment solution, and dilution buffer solution were added, 
mixed, and poured onto the membrane. Immobilon Western Chemiluminescent HRP Substrate was used for color reaction.

\section{RNA Library Construction and Sequencing}

High-throughput sequencing service was provided by CloudSeq Biotech (Shanghai, China). Transcriptome high-throughput sequencing and subsequent bioinformatics analyses were also performed by CloudSeq Biotech (Shanghai, China). Briefly, total RNA was used to remove the rRNAs using the Ribo-Zero rRNA Removal Kit (Illumina, USA) according to the manufacturer's instructions. RNA libraries were constructed using rRNAdepleted RNAs with the TruSeq Stranded Total RNA Library Prep Kit (Illumina, USA) according to the manufacturer's instructions. Libraries were checked for quality, and they were quantified using the Bioanalyzer 2100 system (Agilent Technologies, USA). Furthermore, $10 \mathrm{pM}$ libraries were denatured as single-stranded DNA molecules, captured on Illumina flow cells, amplified in situ as clusters, and finally sequenced for 150 cycles on an Illumina HiSeq Sequencer according to the manufacturer's instructions.

\section{Bioinformatics Analysis}

For circRNA, high-quality reads were aligned to the reference genome/transcriptome with STAR software (v2.5.1b) and circRNAs were detected and identified with DCC software (v0.4.4). edgeR software (v3.16.5) was used to normalize the data and perform analysis of differentially expressed circRNAs. $\mathrm{GO}$ and KEGG analyses were performed for the differentially expressed circRNA-associated genes.

For LncRNA and mRNA, high-quality reads were aligned to the human reference genome (UCSC hg19) with HISAT2 software (v2.0.4). Then, guided by the Ensembl gtf gene annotation file, the Cuffdiff program (v2.2.1, part of Cufflinks software) was used to get the FPKM (fragments per kilobase of exon model per million reads mapped) for the expression profiles of LncRNA and mRNA. Accordingly, fold change and $p$-values were calculated based on FPKM, and differentially expressed LncRNAs and mRNAs were identified. LncRNA target genes were predicted by locations in relation to nearby genes, and GO and pathway analyses were performed on these target genes.

\section{Construction of circRNA-miRNA ceRNA Network}

CircRNA-miRNA interactions were predicted using miRcode (http://www.mircode.org/) and TargetScan (http://www. targetscan.org/vert_72/) based on seed-match sequences. The circRNA-miRNA network was then constructed using Cytoscape software (http://www.cytoscape.org/).

\section{Validation of Differentially Expressed circRNAs}

Total RNA was extracted by TRIzol (Invitrogen Life Technologies, Shanghai, China) to synthesize cDNA via reverse transcription. Quantitative real-time PCR was performed on the ViiA 7 Real-
Time PCR System (Applied Biosystems) using the qPCR SYBR Green Master Mix (CloudSeq). Primer design was as follows: chr13: 50054355-50057699+ (F 5'-CCTGAATCCAAGACAGCCA-3', R 5'-AAGGGGGAAGTTाTGGCA-3'), chr18: 21644104-21649235+ (F 5'-GAAAATCCGCCCCCTCTA-3', R 5'-TGACAAAGCTGGCTCCAA-3'), chr7: 22330794-22357656- (F 5'-CATTCCTGCCAGAGGTGG-3', R 5'-TGGGAAGGCGTATGTCAA-3'), chr2: 15629018-15651474- (F 5'-CATCTGGGCGATTCCATC-3', R 5'- AАCCCCGTCTCCACCATT-3'), and ACTB (F5'-GTGGCCGAGGACTTGATTG-3', R 5'-CCTGTAACAACGCATCTCATATT-3'). The target RNA and internal parameters of each sample were subjected to real-time PCR, which was repeated three times. The data were analyzed by the $2^{-\Delta \Delta C}$ method.

\section{Statistical Analysis}

All of the experimental data are presented as mean \pm standard deviation (SD), and the t-test was used for comparisons between the two groups. Values of $p<0.05$ were considered to be significantly different. GraphPad Prism 5 software was used for statistical analysis.

\section{Results}

\section{Construction of HL-60/ADM Drug-Resistant Cell Lines}

Adriamycin resistance was induced in HL-60 cells via a combination of the concentration gradient method and the impact method (high-dose intermittent induction method) according to the literature [16], and it took 8 months to obtain $\mathrm{HL}-60 / A D M$ resistant cell lines. $\mathrm{IC}_{50}$ detection is shown in Figure $1 \mathrm{~A}$. The expression of the drug resistance protein $\mathrm{P}-\mathrm{gp}$ in $\mathrm{HL}-60 / A D M$ resistant cells was significantly higher than that in $\mathrm{HL}-60$ cells, with significance at $\mathrm{p}<0.01$ (Figures $1 \mathrm{~B}$ and $1 \mathrm{C}$ ).

\section{Expression of circRNA, LncRNA, and mRNA in Resistant Cells}

To analyze the gene expression of resistant $A M L$ cells, we performed high-throughput sequencing of circRNA, LncRNA, and $m R N A$, and we screened differentially expressed genes. Hierarchical cluster analysis showed that the expression patterns
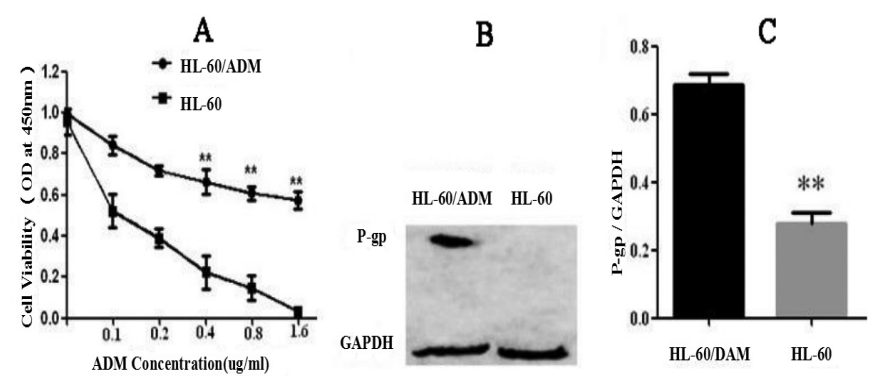

Figure 1. Detection of HL-60/ADM resistance: A) HL-60/ADM IC test, where the ADM concentration gradient was set at $0,0.1,0.2$, $0.4,0.8$, and $1.6 \mu \mathrm{g} / \mathrm{mL}$. The horizontal axis is ADM concentration and vertical axis is inhibition rate. B) Expression of drug-resistance related protein P-gp. C) P-gp/GAPDH ratio $\left({ }^{* *} p<0.01\right)$. 
of drug-resistant and drug-sensitive cells were significantly different (circRNA, Figure 2A; LncRNA, Figure 2D; mRNA, Figure $2 \mathrm{G})$. Scatter plots were used to evaluate circRNA between drug-resistant and drug-sensitive cells. LncRNA and mRNA signal values were normalized to log2 values for visualization of expression differences (Figures 2B, 2E, and 2H, respectively). Volcanic maps were constructed based on fold change ( $F C \geq 1.2)$ and $p$-value $(<0.05)$, and volcano maps of the differentially expressed genes between these two different conditions are provided in Figures $2 \mathrm{C}, 2 \mathrm{~F}$, and $2 \mathrm{I}$. The general characteristics of RNA include RNA type, length, and localization distribution, as shown in Figures $2 \mathrm{~J}-2 \mathrm{~L}$. The results showed that resistant AML cells differentially expressed 1824 circRNAs, 2414 LncRNAs, and 5346 mRNAs.

\section{Functional Analysis of Differentially Expressed circRNA, LncRNA, and $\mathrm{mRNA}$}

To explore the underlying genomics mechanisms involved in the developmental disorders of AML tumorigenesis, GO and KEGG pathway enrichment analyses of differentially expressed genes were used to evaluate candidate RNA functions. The GO terms with the highest enrichment scores for upregulated circRNA targeting were ribonucleoside triphosphate catabolic process and purine ribonucleoside triphosphate catabolic process (BP),

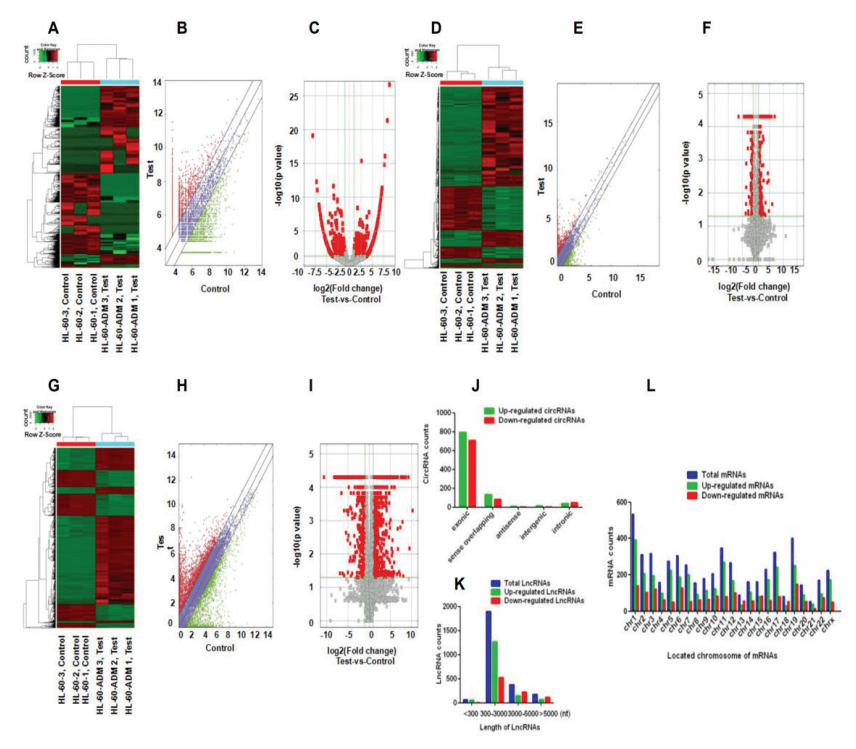

Figure 2. Differential expression of circRNA, LncRNA, and mRNA in HL-60/ADM. A-C) Hierarchical clustering, scatter plots, and volcano plots of the differentially expressed circRNAs in HL60 and HL-60/ADM, respectively. D-F) Hierarchical clustering, scatter plots, and volcano plots of the differentially expressed LncRNAs in HL-60 and HL-60/ADM, respectively. G-I) Hierarchical clustering, scatter plots, and volcano plots of the differentially expressed mRNAs in HL-60 and HL-60/ADM, respectively. J) The catalog of differentially expressed circRNAs. K) Distribution of differentially expressed LncRNAs based on the length of nuclear acids. L) Distribution of differentially expressed mRNAs based on the location on human chromosomes. intracellular (CC), and adenyl ribonucleotide binding (MF); for LncRNA, the GO terms involved macromolecule modification $(\mathrm{BP})$, cornified envelope (CC), and protein homodimerization activity (MF); and anatomical structure morphogenesis (BP), cytoplasm (CC), and protein binding (MF) belonged to the $\mathrm{GO}$ analysis of mRNA. Furthermore, KEGG pathway analysis was performed to predict potential module functions. The KEGG analysis results were as follows: for circRNA, the B cell receptor signaling pathway (hsa04662), T cell receptor signaling pathway (hsa04660), MAPK signaling pathway (hsa04010), and mTOR signaling pathway (hsa04150); for LncRNA, signaling pathways regulating pluripotency of stem cells (hsa04550); and for mRNA, the Wnt signaling pathway (hsa04310), Rap1 signaling pathway (hsa04015), p53 signaling pathway (hsa04115), and VEGF signaling pathway (hsa04370). These are closely related to cancer progression and are significantly enriched in AML (Figure 3).

\section{Construction of circRNA-miRNA ceRNA Network}

To fully understand the underlying mechanisms of circRNA and AML development, based on differentially expressed circRNA data, we used a database to predict target miRNAs interacting with circRNA, and Cytoscape was used to construct a circRNA-targeted miRNA gene network map (Figure 4). For a particular miRNA, circRNA has many targets, and the network map illustrates the first five predicted miRNA targets that differentially express circRNA.

\section{Validation of circRNA Expression by RT-qPCR}

Two upregulated genes (chr7: 2330794-22357656- and chr2: 15629018-15651474-) and two downregulated genes (chr13: 50054355-50057699+ and chr18: 21644104-21649235+)

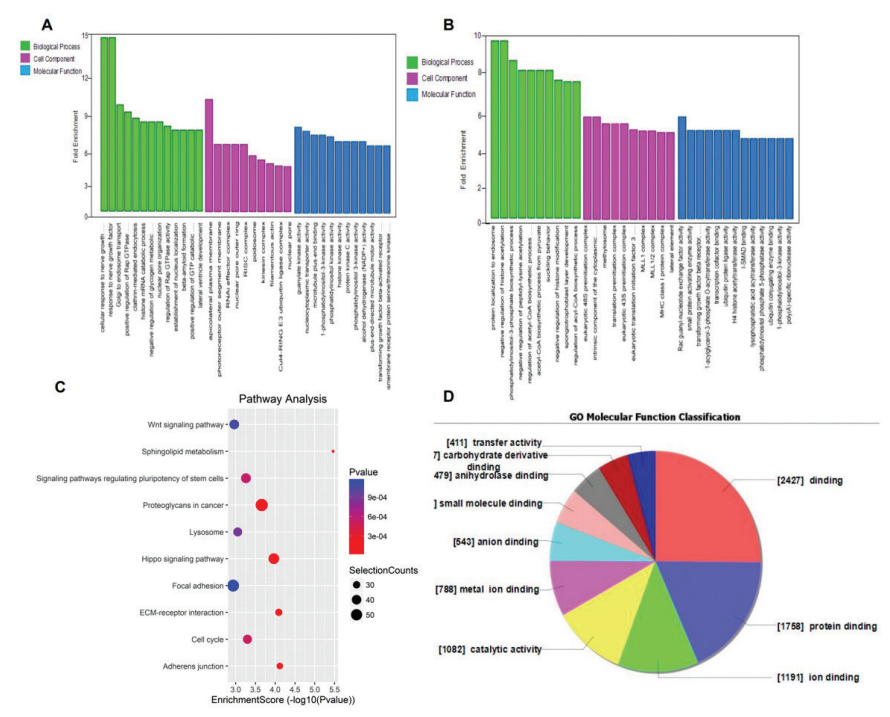

Figure 3. GO and KEGG pathway analysis of circRNA, LncRNA, and mRNA. A-B) Analysis of GO in terms of upregulation and downregulation of circRNA. C) Pathway analysis of upregulation of LncRNA. D) G0 molecular function classification for upregulation of mRNA. 
were selected from the circRNAs with differential expression. Differentially expressed circRNA levels were verified by RTqPCR. As shown in Figure 5, the results of four circRNAs were consistent with the trend observed in circRNA sequencing.

\section{Discussion}

At present, chemotherapy is still one of the main treatments for leukemia. However, multidrug resistance and treatment

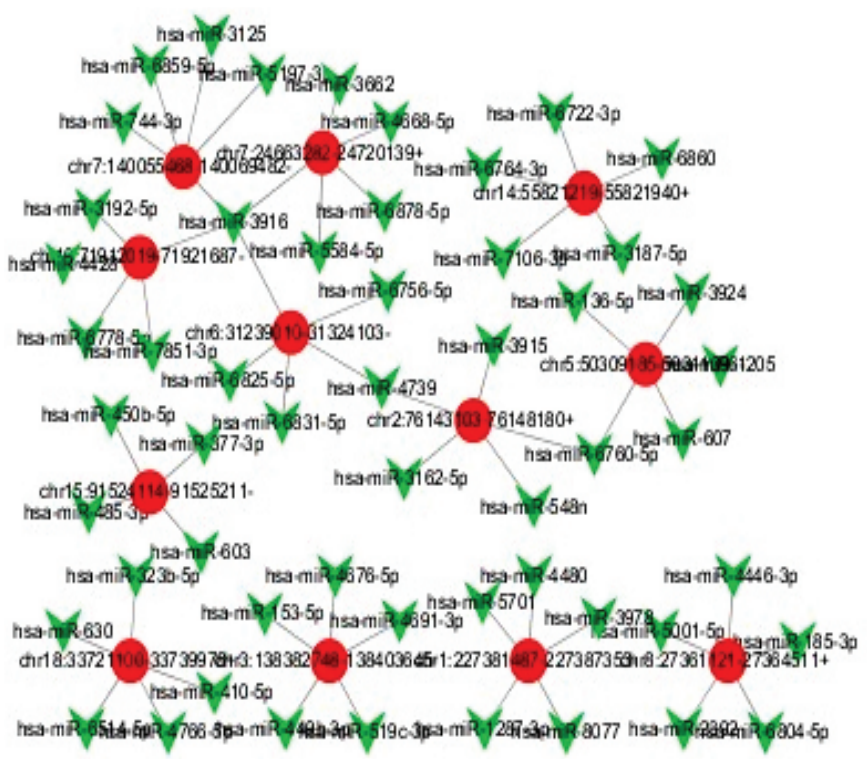

Figure 4. Network of twelve differentially expressed circRNA and miRNA genes predicted in drug-resistant cells. CircRNA: Red circles; MiRNA: green polygons. Twelve different genes were selected from the upregulated circRNAs to construct the circRNAtargeted miRNA gene network. Each circRNA is shown with five miRNA predicted targets.
A

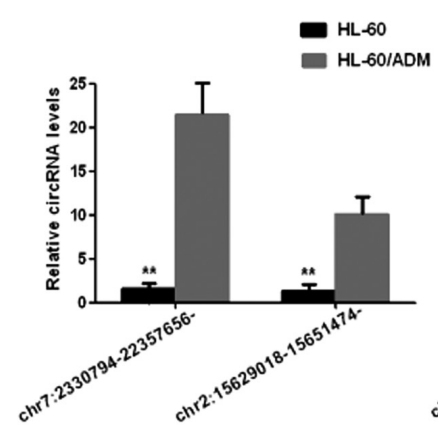

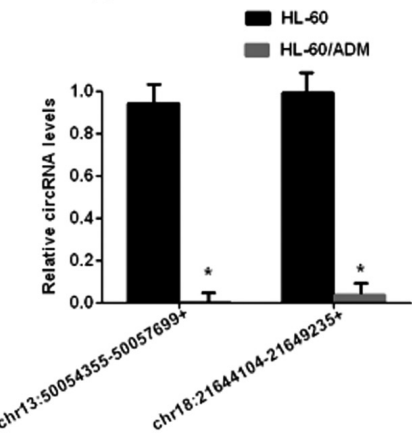

Figure 5. Expression levels of differentially expressed circRNA were detected by RT-qPCR. The horizontal axis is genes and the vertical axis is circRNA expression levels. A) Two genes, chr7:233079422357656- and chr2:15629018-15651474, were selected from circRNA with upregulated expression. B) chr13:5005435550057699+ and chr18:21644104-21649235+ were selected from downregulated circRNAs. The target RNA and internal parameters of each sample were subjected to real-time PCR, which was repeated three times. The data were analyzed by $2-{ }_{T}^{\Delta \Delta C}$ method. ${ }^{* *} \mathrm{p}<0.01,{ }^{*} \mathrm{p}<0.05$. are key factors in the failure of leukemia treatment. Several factors are involved in the mechanism of leukemia resistance, including $A B C$ transporter-mediated multidrug resistance [17], DNA repair abnormalities [18], variations in the bone marrow microenvironment [19], and abnormal expression of noncoding RNAs including circRNA, miRNA, and LncRNA [20]. Undeniably, ncRNAs have opened up new prospects for AML diagnosis, prognosis, and treatment. Indeed, the expression of specific ncRNAs such as circRNAs and LncRNAs could assist clinicians in classifying subtypes, evaluating prognosis, and predicting the response to drug treatment in AML. Garzon et al. [21] evaluated the associations of LncRNA expression with clinical characteristics, gene mutations, and outcomes and constructed an LncRNA score including 48 LncRNAs for independently predicting outcome prognosis, confirming that LncRNAs can assist in predicting clinical outcomes in older patients with CN-AML. Moreover, Li and Sun [22] reported that SNHG5 overexpression was frequently observed in $\mathrm{AML}$ patients with advanced $F A B$ classification and unfavorable cytogenetics. Furthermore, a higher SNHG5 expression level was also associated with shorter overall survival. However, comprehensive analyses of the profiles of differentially expressed circRNAs, LncRNAs, and mRNAs in resistant AML cells have not been studied. Thus, we explored the expression profiles and predicted the potential functions of circRNAs, LncRNAs, and mRNAs in resistant AML cells by utilizing RNA high-throughput sequencing and bioinformatics analysis.

The numbers of differentially expressed genes of circRNAs, LncRNAs, and mRNA in resistant AML cells are 1824, 2414, and 5346, respectively. G0 and KEGG pathway analyses of differentially expressed LncRNAs mainly revealed protein domain specific binding and protein dimerization activity. This provides a basis for important contributions to the development and resistance of leukemia. Although the understanding of the nature and function of circRNAs is still limited, it is undeniable that circRNA has always been a research hotspot in the field of ncRNAs, which particularly regulate miRNA-targeted gene expression as ceRNA molecules [23,24]. GO and KEGG pathway analyses predicted that these differentially expressed circRNA functions were related to tumor development, drug-resistant regulation, and metabolism-related pathways.

GO analysis mainly revealed involvement with PI3K activity, transforming growth factor- $\beta$ (TGF- $\beta$ ) receptor, and cellular metabolism. Sui et al. [25] reported that activation of the PI3K/Akt/NF-KB pathway promotes P-gp expression, and the inhibition of this pathway reverses P-gp-mediated multidrug resistance. Zhou et al. explored the effect of the PI3K-specific inhibitor ZSTK474 on K562/A02 cells and their results showed that ZSTK474 reversed the resistance of K562/A02 cells to ADM and imatinib by downregulating P-gp expression; accordingly, the target of ZSTK474 for CML treatment is PI3K [26]. It can be 
seen that PI3K activity plays an important role in the regulation of drug resistance in leukemia. Results of KEGG analysis indicated that the upregulated circRNA in drug-resistant cells was mainly related to the $m$ TOR signaling pathway, MAPK signaling pathway, and Akt signaling pathway. The PI3K/Akt signaling pathway maintains a close relationship between tumor cell multidrug resistance and $\mathrm{P}-\mathrm{gp}$. Studies have shown that activation of the PI3K/Akt signaling pathway increases drug efflux via the ATPbinding cassette $(A B C)$ transporter [27], while the blocking of $\mathrm{PI} 3 \mathrm{~K} /$ Akt signaling pathways leads to downregulation of P-gp and MRP1 expression, restoring sensitivity to chemotherapeutic drugs [28].

According to the ceRNA theory, a circRNA-miRNA regulation network is present in cases of resistant AML. Moreover, differentially expressed circRNAs-miRNA interactions were predicted and the potential molecular mechanisms were further explored. Among these predicted potential target miRNAs, hsa-miR-24-2-59 is reported to be upregulated during hematopoietic cell terminal differentiation, suppressing MYC expression [29]. Hsa-miR-181b-5p may play a prominent role in pituitary adenoma as an effective biomarker and therapeutic target [30]. However, there are some limitations to this study, such as a small sample size and the in vitro research being conducted only on HL-60 cells. The next step of this work will be to verify the expression of LncRNAs and circRNAs in AML patients and to study the mechanisms of LncRNAs and circRNAs in the development of resistant AML.

\section{Conclusion}

Even though only resistance to adriamycin was assessed in this study, the results suggest that the expression changes of circRNA/LncRNA regulate the cell resistance of $A M L$, providing a new theoretical basis for the further understanding of multidrug resistance mechanisms and targeted therapies in AML.

\section{Ethics}

Ethics Committee Approval: No human studies were involved in this work.

Informed Consent: This study did not involve animal and human ethics.

\section{Authorship Contributions}

Concept: Q.L.; Data Collection or Processing: M.L., F.M.; Analysis or Interpretation: F.M.

Conflict of Interest: The authors have no conflicts of interest to declare.

Financial Disclosure: This work was supported by the Science and Technology Project of the Science and Technology Department of Guizhou Province (Qian Ke He Basics [2016]1129), the Science and Technology Fund Project of the Health and Family Planning Commission of Guizhou Province (gzwjkj2016-1-025), and the Chinese Medicine Science and Technology Research Project of the Guizhou Provincial Administration of Traditional Chinese Medicine (QZZYY-2017-035).

\section{References}

1. Li XX, Zhou JD, Wen XM, Zhang TJ, Wu DH, Deng ZQ, Zhang ZH, Lian XY, He PF, Yao XY, Lin J, Qian J. Increased MCL-1 expression predicts poor prognosis and disease recurrence in acute myeloid leukemia. Onco Targets Ther 2019;12:3295-3304.

2. Shang J, Chen WM, Liu S, Wang ZH, Wei TN, Chen ZZ, Wu WB. CircPAN3 contributes to drug resistance in acute myeloid leukemia through regulation of autophagy. Leuk Res 2019;85:106198.

3. Lai QY, He YZ, Peng XW, Zhou X, Liang D, Wang L. Histone deacetylase 1 induced by neddylation inhibition contributes to drug resistance in acute myelogenous leukemia. Cell Commun Signal 2019;17:86.

4. Bertone $P$, Stolc $V$, Royce $T E$, Rozowsky JS, Urban $A E$, Zhu X, Rinn JL, Tongprasit W, Samanta M, Weissman S, Gerstein M, Snyder M. Global identification of human transcribed sequences with genome tiling arrays. Science 2004;306:2242-2246.

5. Kapranov P, Cheng J, Dike S, Nix DA, Duttagupta R, Willingham AT, Stadler PF, Hertel J, Hackermüller J, Hofacker IL, Bell I, Cheung E, Drenkow J, Dumais E, Patel S, Helt G, Ganesh M, Ghosh S, Piccolboni A, Sementchenko V, Tammana H, Gingeras TR. RNA maps reveal new RNA classes and a possible function for pervasive transcription. Science 2007;316:1484-1488.

6. Guttman M, Rinn JL. Modular regulatory principles of large noncoding. Nature 2012;482:339-346.

7. Li Z, Zhao X, Zhou Y, Liu Y, Zhou Q, Ye H, Wang Y, Zeng J, Song Y, Gao W, Zheng S, Zhuang B, Chen H, Li W, Li H, Li H, Fu Z, Chen R. The long noncoding RNA HOTTIP promotes progression and gemcitabine resistance by regulating HOXA13 in pancreatic cancer. J Transl Med 2015;13:84.

8. Li Z, Zhao L, Wang 0 . Overexpression of long non-coding RNA HOTIP increases chemoresistance of osteosarcoma cell by activating the Wnt/ $\beta$ catenin pathway. Am J Transl Res 2016;8:2385-2393.

9. Qu L, Ding J, Chen C, Wu ZJ, Liu B, Gao Y, Chen W, Liu F, Sun W, Li XF, Wang X, Wang Y, Xu ZY, Gao L, Yang Q, Xu B, Li YM, Fang ZY, Xu ZP, Bao Y, Wu DS, Miao $X$, Sun HY, Sun YH, Wang HY, Wang LH. Exosome-transmitted IncARSR promotes sunitinib resistance in renal cancer by acting as a competing endogenous RNA. Cancer Cell 2016;29:653-668.

10. Wilusz JE, Sharp PA. Molecular biology. A circuitous route to noncoding RNA. Science 2013;340:440-441.

11. Jeck WR, Sorrentino JA, Wang K, Slevin MK, Burd CE, Liu J, Marzluff WF, Sharpless NE. Circular RNAs are abundant, conserved, and associated with ALU repeats. RNA 2013;19:141-157.

12. Grisendi S, Mecucci C, Falini B, Pandolfi PP. Nucleophosmin and cancer. Nat Rev Cancer 2006;6:493-505.

13. Salzman J, Chen RE, Olsen MN, Wang PL, Brown PO. Cell-type specific features of circular RNA expression. PLoS Genet 2013;9:e1003777.

14. Memczak S, Jens M, Elefsinioti A, Torti F, Krueger J, Rybak A, Maier $L$, Mackowiak SD, Gregersen LH, Munschauer M, Loewer A, Ziebold U, Landthaler M, Kocks C, le Noble F, Rajewsky N. Circular RNAs are a large class of animal RNAs with regulatory potency. Nature 2013;495:333-338.

15. Rybak-Wolf $A$, Stottmeister $C$, Glažar $P$, Jens $M$, Pino N, Giusti $S$, Hanan $M$, Behm M, Bartok 0, Ashwal-Fluss R, Herzog M, Schreyer L, Papavasileiou P, Ivanov A, Öhman M, Refojo D, Kadener S, Rajewsky N. Circular RNAs in the mammalian brain are highly abundant, conserved, and dynamically expressed. Mol Cell 2015;58:870-885. 
16. Chen J, Wei H, Cheng J, Xie B, Wang B, Yi J, Tian B, Liu Z, Wang F, Zhang Z. Characteristics of doxorubicin-selected multidrug-resistant human leukemia HL-60 cells with tolerance to arsenic trioxide and contribution of leukemia stem cells. Oncol Lett 2018;15:1255-1262.

17. Liu B, Li U, Gong X, Zhang W, Zhang H, Zhao L. Co-expression of ATP binding cassette transporters is associated with poor prognosis in acute myeloid leukemia. Oncol Lett 2018;15:6671-6677.

18. Rushing AW, Hoang $\mathrm{K}$, Polakowski N, Lemasson I. The human T-cell leukemia virus type 1 basic leucine zipper factor attenuates repair of double-stranded DNA breaks via nonhomologous end joining. J Virol 2018;92:e00672-18.

19. Su M, Chang YT, Hernandez D, Jones RJ, Ghiaur G. Regulation of drug metabolizing enzymes in the leukaemic bone marrow microenvironment. J Cell Mol Med 2019;23:4111-4117.

20. Calin GA. The noncoding RNA revolution-three decades and still going strong. Mol Oncol 2019;13:3.

21. Garzon R, Volinia S, Papaioannou D, Nicolet D, Kohlschmidt J, Yan PS, Mrózek K, Bucci D, Carroll AJ, Baer MR, Wetzler M, Carter TH, Powell BL, Kolitz JE, Moore JO, Eisfeld AK, Blachly JS, Blum W, Caligiuri MA, Stone RM, Marcucci G, Croce CM, Byrd JC, Bloomfield CD. Expression and prognostic impact of IncRNAs in acute myeloid leukemia. Proc Natl Acad Sci U S A 2014;111:18679-18684.

22. Li J, Sun CK. Long noncoding RNA SNHG5 is up-regulated and serves as a potential prognostic biomarker in acute myeloid leukemia. Eur Rev Med Pharmacol Sci 2018;22:3342-3347.

23. Hansen $\mathrm{TB}$, Jensen $\mathrm{TI}$, Clausen $\mathrm{BH}$, Bramsen JB, Finsen $\mathrm{B}$, Damgaard $\mathrm{CK}$, Kjems J. Natural RNA circles function as efficient microRNA sponges. Nature 2013;495:384-388.
24. Liu J, Liu T, Wang $X$, He A. Circles reshaping the RNA world: from waste to treasure. Mol Cancer 2017;16:58.

25. Sui $H$, Pan SF, Feng $Y$, Jin BH, Liu X, Zhou LH, Hou FG, Wang WH, Fu XL, Han ZF, Ren JL, Shi XL, Zhu HR, Li Q. Zuo Jin Wan reverses P-gp-mediated drugresistance by inhibiting activation of the PI3K/Akt/NF-kB pathway. BMC Complement Altern Med 2014;14:279.

26. Zhou , Chen $Y$, Chen $X$, Zhao W, Zhong Y, Wang R, Jin M, Oiu Y, Kong D. In vitro antileukemia activity of ZSTK474 on K562 and multidrug resistant K562/A02 cells. Int J Biol Sci 2016;12:631-638.

27. Zhang X, Dong W, Zhou H, Li H, Wang N, Miao X, Jia L. $\alpha$-2,8-Sialyltransferase is involved in the development of multidrug resistance via $\mathrm{PI} 3 \mathrm{~K} / \mathrm{Akt}$ pathway in human chronic myeloid leukemia. IUBMB Life 2015;67:77-87.

28. Ma H, Cheng L, Hao K, Li Y, Song $X$, Zhou H, Jia L. Reversal effect of ST6GAL 1 on multidrug resistance in human leukemia by regulating the PI3K/Akt pathway and the expression of P-gp and MRP1. PLoS One 2014;9:e85113.

29. Lal $A$, Navarro $F$, Maher CA, Maliszewski LE, Yan N, O'Day $E$, Chowdhury D, Dykxhoorn DM, Tsai P, Hofmann O, Becker KG, Gorospe M, Hide W, Lieberman J. miR-24 inhibits cell proliferation by targeting E2F2, MYC, and other cell-cycle genes via binding to "seedless" 3'UTR microRNA recognition elements. Mol Cell 2009;35:610-625.

30. Wu S, Gu Y, Huang Y, Wong TC, Ding H, Liu T, Zhang Y, Zhang X. Novel biomarkers for non-functioning invasive pituitary adenomas were identified by using analysis of microRNAs expression profile. Biochem Genet 2017;55:253-267. 